REF - ISSN 1808-0804 Vol. IX (1), 18 - 39, 2012.

\title{
DISCOVERY OF ANTIFUNGAL PLANTS IN ARGENTINEAN SAN LUIS PROVINCE: ETHNOMEDICAL INFORMATION OR RANDOM SELECTION?
}

DESCOBERTA DAS PLANTAS ANTIFÚNGICAS EM SAN LUIS PROVÍNCIA DE ARGENTINA ETNOMEDICINA INFORMAÇÕES OU SELEÇÃO ALEATÓRIA?

\author{
A. Postigo, ${ }^{1}$ L. Svetaz, ${ }^{1}$ M. Derita, ${ }^{1}$ M.A. Gette, ${ }^{2}$ M. Petenatti, ${ }^{2}$ L. Del Vitto, ${ }^{2}$ \\ E. Petenatti, ${ }^{2}$ and S. Zacchino ${ }^{1 *}$ \\ ${ }^{1}$ Farmacognosia, Facultad de Ciencias Bioquímicas y Farmacéuticas, Universidad \\ Nacional de Rosario, Rosario, Argentina \\ ${ }^{2}$ Farmacognosia, Facultad de Química, Bioquímica y Farmacia y Herbario, \\ Universidad Nacional de San Luis, San Luis, Argentina \\ *Autor para correspondencia: szaabgil@citynet.net.ar
}

Recebido em 21/05/2009, Aceito em 22/07/2010.

ABSTRACT: This study reports the antifungal evaluation of eighty-two crude methanolic extracts of plants from San Luis province, Argentina, which were selected on the basis of their reported ethnomedical uses and compared them with plants selected at random.

The extracts were screened for antifungal properties against yeasts and filamentous fungi and the concentration that completely inhibited the fungal growth (MIC) was determined. For the antifungal evaluation, the microbroth dilution assay recommended by the Clinical and Laboratory Standards Institute was used. For the statistical analysis the Pearson's Chi Square test and the Score's test were used.

The results showed that 25 out of the 40 PE plants $(62.5 \%)$ were active (MIC $\leq 1000$ $\mu \mathrm{g} / \mathrm{mL}$ ) unless in one group of fungi; 6 (15\%) were active in yeasts; 4 (10\%) were active in Aspergillus spp. and 25 (62.5\%) were active in dermatophytes. In turn, among the 42 PW species, $4(10 \%)$ were active (MIC $\leq 1000 \mathrm{ug} / \mathrm{mL}$ ) unless in one group of fungi, 1 $(2.5 \%)$ were active in yeasts, $1(2.5 \%)$ were active in Aspergillus spp. and $4(10 \%)$ were active in dermatophytes. In addition, it is observed a clear trend of extracts to display 
Postigo, A. Svetaz, L. Derita, M. Gette, M. A. Petenatti, M. Del Vitto,L. Petenatti, E. Zacchino, S. Revista Eletrônica de Farmácia Vol. IX (1), 18 - 39, 2012.

lower MICs within PE group, against dermatophytes ( $p<0.01$ ) fungi responsible of superficial infections. These findings suggest that the ethnopharmacological approach is useful in guiding the discovery of antifungal plants.

KEYWORDS: Ethnomedical information, San Luis province, Argentinean plants, antifungal activity

RESUMO: Este estudo mostra a avaliação da atividade antifúngica de oitenta e dois extratos metanólicos de plantas na província de San Luis, Argentina, que foram selecionados com base em seus usos ethnomedical relatados e comparados com as plantas selecionadas aleatoriamente.

Os extratos foram selecionados para as propriedades antifúngicas contra leveduras e fungos filamentosos, ea concentração que inibiu completamente o crescimento de fungos (MIC) foi determinado. Para a avaliação da atividade antifúngica, o teste de microdiluição recomendados pelo Clinical Laboratory Standards Institute. Para a análise estatística de Pearson Chi quadrado e teste do Score foram utilizados.

Os resultados mostraram que 25 das 40 plantas de PE $(62,5 \%)$ eram ativos (MIC $\leq 1000$ $1,000 \mu \mathrm{g} / \mathrm{mL}$ ) pelo menos em um grupo de fungos, 6 (15\%) estavam ativos em leveduras, 4 (10\%) estavam ativos em Aspergillus spp. e 25 (62,5\%) estavam ativos em dermatófitos. Além disso, observa-se uma clara tendência de extratos para mostrar MICs menores no grupo PE, contra dermatófitos $(p<0,01)$ fungos responsáveis de infecções superficiais. Estes resultados sugerem que a abordagem etnofarmacológica é útil para orientar a descoberta de plantas antifúngicos.

PALAVRAS-CHAVES: Informação ethnomedical, província de San Luis, Argentina plantas, atividade antifúngica

\section{INTRODUCTION}

Invasive fungal infections have increased in frequency in the past two decades, having an enormous impact on morbidity and mortality in immunocompromised patients ${ }^{(1-2)}$. Fungi with low virulence for immunocompetent persons, can be life-threatening ${ }^{(3)}$ for neonates, cancer patients receiving chemotherapy, organ transplant and burn patients, in addition to those with acquired immunodeficiency syndrome (AIDS). Other risk factors include corticosteroid and antibiotic treatments, diabetes, epidermic and dermis injuries, malnutrition, neutropenia, and 
Postigo, A. Svetaz, L. Derita, M. Gette, M. A. Petenatti, M. Del Vitto,L. Petenatti, E. Zacchino, S. Revista Eletrônica de Farmácia Vol. IX (1), 18 - 39, 2012.

surgery ${ }^{(4)}$. In addition, an increasing number of normal individuals, including children in third-world nations ${ }^{(5-6)}$ that receive deficient sanitary attention and education, suffers superficial fungal infections (those involving the skin and mucosal surfaces) which diminish the quality of their lives.

Although it appears to be a big armamentarium of antifungal drugs in clinical use, in fact a modest number of drugs, derived from five antifungal classes, are available ${ }^{(7)}$.

All of the available antifungals possess some of the following inconveniences: they have a limited spectrum of action, are fungistatic rather than fungicide thus producing recurrence, develop resistance or are toxic $^{(8)}$.

Plants provide countless opportunities for the isolation of new antifungal compounds because of the peerless availability of chemical diversity ${ }^{(9)}$; in fact, numerous antifungal compounds have been isolated from them ${ }^{(10-13)}$ among many others.

But the first important concern within a program of discovery of new plants with antifungal properties is the selection of species to be submitted to biological evaluation.

According to a recent review of Ríos and Recio ${ }^{(14)}$ a wide range of criteria have been followed to select plants to be submitted to antimicrobial studies. Some studies focused on the ethnopharmacological uses; others, investigated plants growing in a specific region or country; a third group focused on the finding of inhibitors of one or more clinically important fungal species with an at random selection of plants.

Among the different concluding recommendations, Ríos and Recio(14) suggested to avoid the at random criterion and to select plants following an ethnopharmacological perspective since this approach appeared to enhance the probability of success in new drugfinding efforts. These authors based their recommendation on some works ${ }^{(15-19)}$ that, unfortunately, all were performed with the agar diffusion method. In this qualitative method, the diffusion plays an important role in the diameter of the inhibition halo, and therefore it could not reflect the true antifungal activity of the extract $^{(20)}$.

With the aim of determining the importance of following the ethnopharmacology knowledge to detect antifungal plants growing in San Luis province of Argentina in comparison to the at random criterion, we made a bibliographic survey of the ethnomedical information on plants of this region used for ailments related to antifungal infections. 
Postigo, A. Svetaz, L. Derita, M. Gette, M. A. Petenatti, M. Del Vitto,L. Petenatti, E.

Zacchino, S. Revista Eletrônica de Farmácia Vol. IX (1), 18 - 39, 2012.

Among the flora of different regions of Argentina, San Luis province represents one important source of material with pharmacological activity due to its biodiversity.

A five-stage process of documentation, evaluation and analysis of results was conducted: (1) selection of words that could describe the ethnopharmacology use related to fungal infections; (2) a survey of specialized literature on ethnopharmacological uses of plants from San Luis; (3) collection and preparation of extracts of each plant. (4) antifungal evaluation of the selected plants; (5) statistical analysis of the results.

A group of 40 plants used medicinally for ailments related to fungal infections in San Luis province of Argentina (PE) were selected. The following conditions of traditional therapeutic indications were chosen: anti-alopecia, antibiotic, antifungal, antiseptic, dandruff, dental and general infections, diarrhœa, itching, leucorrhœa, respiratory diseases, skin ailments, skin infections, skin ulcerations, urinary infections, vaginitis, venereal diseases, vulnerary, women diseases and wound healing.

Another group of 42 plants without reported traditional use, or with traditional use not related to fungal infections (PW group) was chosen at random and collected in the San Luis province of Argentina.

The taxonomic identity of the plant of both groups was established by the authors, Prof. Elisa Petenatti and Luis Del Vitto.

A crude methanolic extract of aerial parts of each plant was evaluated for antifungal properties against the same panel of fungi with the microbroth dilution assay recommended by the Clinical and Laboratory Standards Institute ${ }^{(22)}$.

\section{MATERIAL AND METHODS}

\section{Plants}

Aerial parts of the plants detailed in Table 1 and 2 were collected in the different environments of San Luis province.

Voucher specimens were deposited at the Herbarium of the National University of San Luis (UNSL) and classified by Professors Elisa Petenatti and Luis Del Vitto.

\section{Extracts preparation}

Aerial parts of each plant species were air dried and then ground in a mill. Powders were submitted to maceration with $\mathrm{MeOH}(3 \mathrm{x}) 24 \mathrm{~h}$ each. Plant extracts were filtered, pooled, vacuum evaporated at $<40{ }^{\circ} \mathrm{C}$ in a rotary 
Postigo, A. Svetaz, L. Derita, M. Gette, M. A. Petenatti, M. Del Vitto,L. Petenatti, E. Zacchino, S. Revista Eletrônica de Farmácia Vol. IX (1), 18 - 39, 2012.

evaporator and stored at $-80{ }^{\circ} \mathrm{C}$ until tested.

\section{Antifungal evaluation}

\section{Microorganisms and media}

For the antifungal evaluation, standardized strains from the American Type Culture Collection (ATCC), Rockville, MD, USA, and Reference Center in Mycology (CEREMIC, C, Rosario, Argentina) were used. Candida albicans ATCC 10231, Candida tropicalis C 131, Saccharomyces cerevisiae ATCC 9763, Cryptococcus neoformans ATCC 32264, Aspergillus flavus ATCC 9170, A. fumigatus ATTC 26934, A. niger ATCC 9029, Trichophyton rubrum C 110, T. mentagrophytes ATCC 9972, M. gypseum C 115 and Epidermophyton floccosum C 114. Strains were grown on Sabouraud-chloramphenicol agar slants for $48 \mathrm{~h}$ at $30{ }^{\circ} \mathrm{C}$, maintained on slopes of Sabouraud-dextrose agar (SDA, Oxoid) and sub-cultured every 15 days to prevent pleomorphic transformations. Inocula were obtained according to reported procedures and adjusted to 1-5 $\times 10^{3}$ cells/spores with colony forming units (CFU) $/ \mathrm{mL}^{(21)}$.

\section{Antifungal susceptibility testing}

Minimal Inhibitory Concentration (MIC) of each extract or compound was determined by using broth microdilution techniques according to the guidelines of the National Committee for Clinical Laboratory Standards for yeasts (M27A2) and for filamentous fungi (M 38 $A)^{(21)}$, MIC values were determined in RPMI-1640 (Sigma, St Louis, Mo, USA) buffered to $\mathrm{pH} 7.0$ with MOPS. Microtiter trays were incubated at $35{ }^{\circ} \mathrm{C}$ for yeasts and hialohyphomycetes and at $28-30{ }^{\circ} \mathrm{C}$ for dermatophyte strains in a moist, dark chamber. MICs were visually recorded at $48 \mathrm{~h}$ for yeasts, and at a time according to the control fungus growth, for the rest of fungi.

For the assay, stock solutions of extracts were two-fold diluted with RPMI-1640 from $1000-0.98 \mu \mathrm{g} / \mathrm{mL}$ (final volume $=100 \mu \mathrm{l}$ ) and a final DMSO concentration $\leq 1 \%$. A volume of $100 \mu \mathrm{l}$ of inoculum suspension was added to each well with the exception of the sterility control where sterile water was added to the well instead. Ketoconazole and Amphotericin B were used as positive controls for yeasts and Aspergillus spp. Terbinafine was used as a positive control for dermatophytes. Endpoints were defined as the lowest concentration of drug resulting in total inhibition (MIC) of visual growth compared to the growth in the control wells containing no antifungal. Tests were made by duplicate. 
Postigo, A. Svetaz, L. Derita, M. Gette, M. A. Petenatti, M. Del Vitto,L. Petenatti, E. Zacchino, S. Revista Eletrônica de Farmácia Vol. IX (1), 18 - 39, 2012.

\section{Statistical analysis}

The comparison of the number of positive plants in PE and PW groups was analyzed with the Chi Square test. $\mathrm{P}<$ 0.05 was considered significant.

\section{RESULTS AND DISCUSSION}

Eighty-two crude methanolic extracts of plants from San Luis province were screened for antifungal properties with the microbroth dilution assay against yeasts and filamentous fungi and the concentration that completely inhibited the fungal growth (MIC) was determined for each extract. A plant with MICs $\leq 1000 \mu \mathrm{g} / \mathrm{mL}$ was considered active.

The fungal panel comprised 11 fungi included yeasts, molds of Aspergillus genus and dermatophytes. Among yeasts, Candida albicans was included because is the main causal agent of fungal infections in immunocompromised hosts, followed by other non-albicans Candida species such as $C$. tropicalis ${ }^{(1)}$. On the other hand, Cryptococcus neoformans is one of the fungus of the panel because it is the main cause of meningoencephalitis in AIDS patients ${ }^{(22)}$. Among molds, Aspergillus fumigatus was included because it is one of the pathogens responsible for invasive, and many times fatal, mycoses in immunocompromised patients. Some other Aspergillus species such as $A$. flavus and $A$. niger are the cause of severe fungal infections too ${ }^{(23,24)}$.

Among dermatophytes, the most common skin mycoses are those known as tineas. Tinea unguium, tinea pedis and tinea manuum are mainly produced by Trichophyton rubrum and $T$. mentagrophytes. Instead, tinea cruris is due to $T$. rubrum and Epidermophyton floccosum, while tineas corporis, capitis and barbae are produced by Microsporum canis and $T$. mentagrophytes ${ }^{(25)}$.

Plants were divided in two groups: group PE included plant species that possess ethnopharmacological uses related to fungal infections (total species in this group $=40)$. Group PW included plant species that possess either ethnopharmacological uses not related to fungal infections or do not possess any reported traditional use $(=40)$. PE and PW are listed alphabetically by family and within family, by genus, in Tables 1 and 2 along with the antifungal activities against the different groups of fungi: yeasts (that comprise Candida and Cryptococcus spp.; Aspergillus spp. which include $A$. flavus, $A$. fumigatus and A. niger and dermatophytes that comprise species of the Microsporum and Trichophyton genus.

Results in Table 1 showed that 25 out of the $40 \mathrm{PE}$ plants $(62.5 \%)$ were 
Postigo, A. Svetaz, L. Derita, M. Gette, M. A. Petenatti, M. Del Vitto,L. Petenatti, E. Zacchino, S. Revista Eletrônica de Farmácia Vol. IX (1), 18 - 39, 2012.

active (MIC $\leq 1000 \mu \mathrm{g} / \mathrm{mL}$ ) unless in one group of fungi; $6(15 \%)$ were active in yeasts; 4 (10\%) were active in Aspergillus spp.; and 25 (62.5\%) were active in dermatophytes.

In turn, among the $40 \mathrm{PW}$ species, $4(10 \%)$ were active (MIC $\leq 1000$ $\mathrm{ug} / \mathrm{mL}$ ) unless in one group of fungi, 1 $(2.5 \%)$ were active in yeasts, 1 (2.5\%) were active in Aspergillus spp. and 4 $(10 \%)$ were active in dermatophytes (Table 2). Data of tables 1 and 2 are schematically showed in Figure 1.

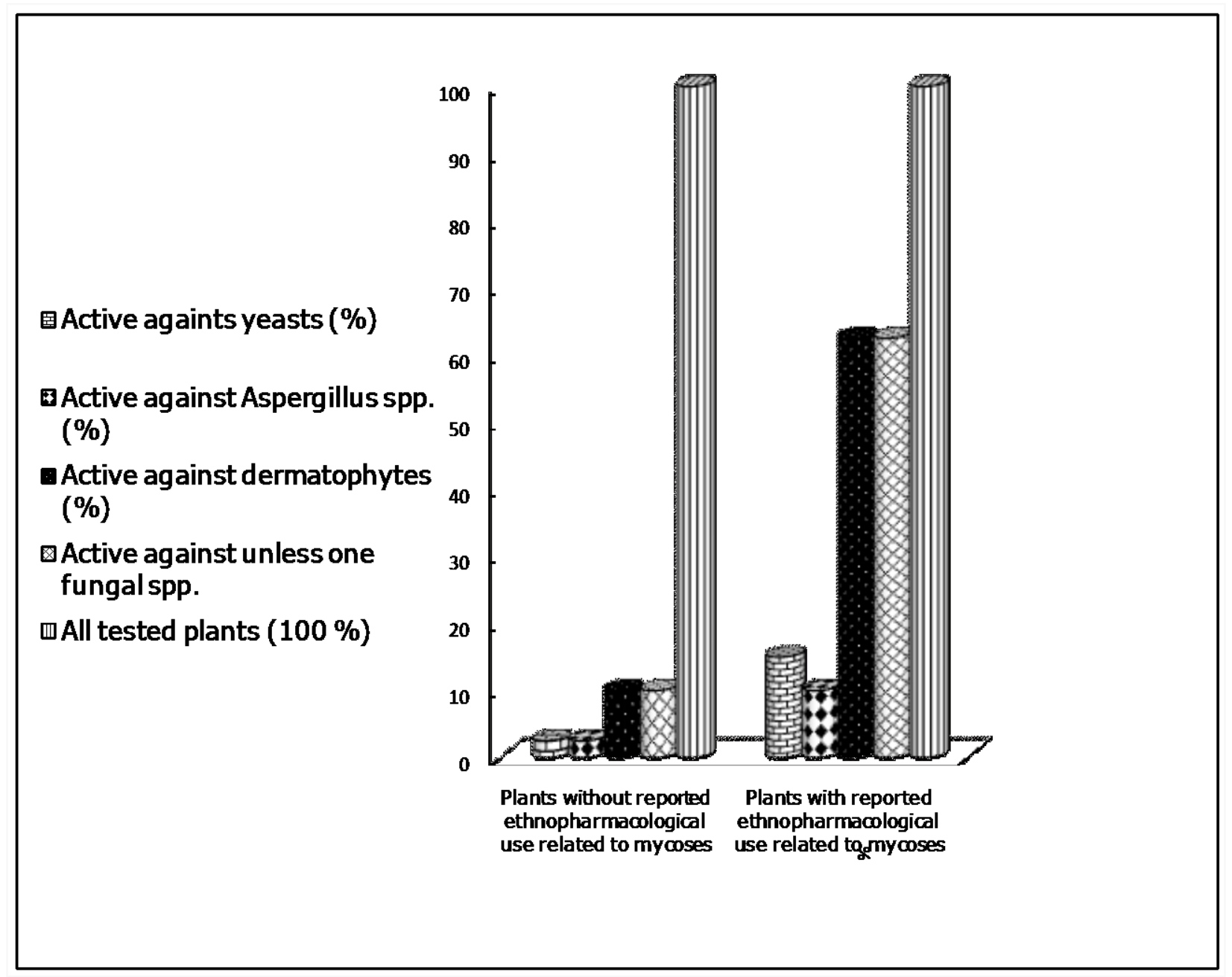

Figure 1: Percentage of active extracts against: unless one fungal species; yeasts; Aspergillus spp.; dermatophytes, within each of both groups of plants: PW (plants without ethnopharmacological uses related to mycoses, bars at the left) and PE (plants with ethnopharmacological uses related to mycoses (bars at right). 
Postigo, A. Svetaz, L. Derita, M. Gette, M. A. Petenatti, M. Del Vitto,L. Petenatti, E. Zacchino, S. Revista Eletrônica de Farmácia Vol. IX (1), 18 - 39, 2012.

Table 1: Antifungal activity (MICs in $\mu \mathrm{g} / \mathrm{mL}$ ) of plant species with reported ethnopharmacological uses to treat conditions related to fungal infections (I: MIC $>1000 \mu \mathrm{g} / \mathrm{mL}$ ).

\begin{tabular}{|c|c|c|c|c|c|c|}
\hline & Family & $\begin{array}{l}\text { Plant name } \\
\text { Voucher } \\
\text { specimen }\end{array}$ & $\begin{array}{l}\text { Ethnopharmacological } \\
\text { uses }\end{array}$ & Yeasts & $\begin{array}{c}\text { Aspergillus } \\
\text { spp. }\end{array}$ & Dermatophytes \\
\hline 1 & Amaranthaceae & $\begin{array}{l}\text { Gomphrena } \\
\text { pulchella Mart. } \\
\text { subsp. rosea } \\
\text { (Griseb.) } \\
\text { Pedersen } \\
\text { Del Vitto \& } \\
\text { Petenatti 9271- } \\
\text { UNSL }\end{array}$ & diarrhoea $^{(27-29)}$ & I & I & $125-250$ \\
\hline 2 & Anacardiaceae & $\begin{array}{l}\text { Schinus } \\
\text { fasciculata } \\
\text { (Griseb.) I.M. } \\
\text { Johnst. Del Vitto } \\
\text { \& Petenatti 9287- } \\
\text { UNSL }\end{array}$ & vulnerary $^{(27,30)}$ & I & I & 1000 \\
\hline 3 & & Schinus molle L. & vulnerary $^{(28)}$ & I & I & $500-1000$ \\
\hline & & $\begin{array}{l}\text { Del Vitto \& } \\
\text { Petenatti 3844- } \\
\text { UNSL }\end{array}$ & & & & \\
\hline 4 & Aristolochiaceae & $\begin{array}{l}\text { Aristolochia } \\
\text { argentina Griseb. } \\
\text { Del Vitto \& } \\
\text { Petenatti 9284- } \\
\text { UNSL }\end{array}$ & antifungal $^{(28)}$ & $\begin{array}{l}250- \\
1000\end{array}$ & $250-1000$ & $125-250$ \\
\hline 5 & Asteraceae & $\begin{array}{l}\text { Baccharis } \\
\text { grisebachii } \\
\text { Hieron. } \\
\text { Del Vitto \& } \\
\text { Petenatti 234- } \\
\text { UNSL }\end{array}$ & vulnerary $^{(31-34)}$ & I & I & $250-500$ \\
\hline 6 & & $\begin{array}{l}\begin{array}{l}\text { Conyza } \\
\text { bonariensis (L.) } \\
\text { Cronquist }\end{array} \\
\text { Del Vitto \& } \\
\text { Petenatti 5546- } \\
\text { UNSL }\end{array}$ & $\begin{array}{l}\text { vulnerary, cicatrizant } \\
\text { (28-39) }\end{array}$ & I & I & I \\
\hline 7 & & $\begin{array}{l}\text { Flaveria bidentis } \\
\text { (L.) Kuntze }\end{array}$ & antifungal, antiseptic ${ }^{(35,40-41)}$ & I & I & I \\
\hline
\end{tabular}


Postigo, A. Svetaz, L. Derita, M. Gette, M. A. Petenatti, M. Del Vitto,L. Petenatti, E. Zacchino, S. Revista Eletrônica de Farmácia Vol. IX (1), 18 - 39, 2012.

Petenatti 9238-

UNSL

\section{Gaillardia} megapotamica

antialopecic, antidandruff and seborrhea ${ }^{(28,42)}$

$250-1000$ (Spreng.) Bak.

var.

megapotamica

Del Vitto \&

Petenatti 5825-

UNSL (Spreng.) Bak. var. radiata

(Griseb.) Baker.

Del Vitto \&

Petenatti 7143-

UNSL

(Spreng.) Bak.

var. scabiosoides

(Arn. ex DC.)

Baker.

Del Vitto \&

Petenatti 5811-

UNSL

(D. Don) Hook. \& Arn. Del Vitto \& Petenatti 7461UNSL

Del Vitto \&

Petenatti 8521-

UNSL

Pterocaulon

Del Vitto \&

Petenatti 2217-

UNSL 
Postigo, A. Svetaz, L. Derita, M. Gette, M. A. Petenatti, M. Del Vitto,L. Petenatti, E. Zacchino, S. Revista Eletrônica de Farmácia Vol. IX (1), 18 - 39, 2012.

15

Thell.

Del Vitto \&

Petenatti 9240-

UNSL

Tagetes filifolia

Lag.

for itch, and healing I

infected wounds ${ }^{(39,47)}$

I

Del Vitto \&

Petenatti 9242-

UNSL

16

$\begin{aligned} & \text { Xanthium } \\ & \text { spinosum L. }\end{aligned}$
Del Vitto \&
$\begin{aligned} & \text { Petenatti 5064- } \\ & \text { UNSL }\end{aligned}$

17 Bignoniaceae

Jacaranda

Wound's cicatrizant

vulnerary, venereous and

skin diseases ${ }^{(28,31,48)}$

$80-1000$

mimosifolia

venereous diseases ${ }^{(31-32)}$

D. Don Del Vitto

\& Petenatti

UNSL 499

18 Bromeliaceae

Tillandsia

bryoides Griseb.

Vulnerary ${ }^{(28-29,33)}$

1000

250

ex Baker

Del Vitto \&

Petenatti 9306-

UNSL

19 Buddlejaceae

Buddleja

Vulnerary ${ }^{(28-29,43)}$

I

I

Griseb.

Del Vitto \&

Petenatti 9316-

UNSL

20 Celtidaceae

Celtis tala Gillies

ex Planch.

desinfectant $^{(49)}$

I

I

Del Vitto \&

Petenatti 3490-

UNSL

21 Convolvulaceae Ipomoea cairica

vulnerary $^{(43,50)}$

I

I

(L.) Sweet Del

Vitto \& Petenatti

6259, UNSL 
Postigo, A. Svetaz, L. Derita, M. Gette, M. A. Petenatti, M. Del Vitto,L. Petenatti, E. Zacchino, S. Revista Eletrônica de Farmácia Vol. IX (1), 18 - 39, 2012.

23 Fabaceae

24

25

26

27 Lythraceae

Oxalidaceae
Müll. Arg.

Del Vitto \&

Petenatti 9262-

UNSL

Acacia caven

(Molina) Molina

antifungal; oral antiseptic,

cicatrizant $^{(27,29,30,32,51-52)}$

Del Vitto \&

Petenatti 6256-

UNSL

Prosopis nigra

for venereous diseases ${ }^{(30,35 \text {, }}$

$43,53)$

(Griseb.) Hieron.

var. nigra

Del Vitto \&

Petenatti 4214-

UNSL

Senna alata (L.)

antiseptic, cicatrizant ${ }^{(29)}$

Roxb. Del Vitto \&

Petenatti 9278-

UNSL

Zuccagnia

antifungal $(28,46)$

$500-$

500-1000

$250-500$

punctata Cav.

Del Vitto \& al.

9325- UNSL

Heimia salicifolia

vulnerary $^{(31,54)}$

I

I

250-1000

(Kunth) Link

Del Vitto,

Petenatti \&

Petenatti 6653

UNSL

Oxalis

genito-urinary $\operatorname{tract}^{(33,55)}$

I

I

500-1000

erythrorhiza

Gillies ex Hook. \&

Arn. MERL

27319-UNSL

Argemone subfusiformis

G.B. Ownbey

oral antiseptic aphta,

cicatrizant, alopecia ${ }^{(27-28,33,}$

I

I

$250-500$

43)

Del Vitto \&

Petenatti 5553-

UNSL

Polygonum

vulnerary, for skin diseases

I

I

250-500 convolvulus $\mathrm{L}$.

UNSL-503

(29) 
Postigo, A. Svetaz, L. Derita, M. Gette, M. A. Petenatti, M. Del Vitto,L. Petenatti, E. Zacchino, S. Revista Eletrônica de Farmácia Vol. IX (1), 18 - 39, 2012.

31

Rosaceae

36

38 Urticaceae
Polygonum
hydropiperoides

Michx.

UNSL-504

Polygonum

punctatum Elliott

UNSL 705 antifungal $^{(29)}$

antiseptic, for skin

diseases $^{(28,56)}$

genito-urinary $\operatorname{tract}^{(33,57)}$

magellanica

(Lam.) Vahl

Kiesling 1361-

UNSL

\section{Fagara coco}

(Gillies) Engl.

Del Vitto \&

Petenatti \& 5763-

UNSL

\section{Cestrum parqui}

vulnerary, skin disorders antiseptic $^{(29,31,33,35,43)}$

L'Hér.

Del Vitto \&

Petenatti 8980-

UNSL

Nicotiana glauca Graham

Del Vitto \&

Petenatti 7473-

UNSL

Physalis viscosa

L.

Del Vitto 8579-

UNSL

\section{Parietaria debilis $\quad$ vulnerary $^{(28,33)}$}

G. Forst.

Del Vitto \&

Petenatti 7563-

UNSL

39 Zygophyllaceae Larrea cuneifolia Cav. Del Vitto \& Petenatti 2818UNSL wounds ${ }^{(27-28,58)}$ antifungal, anti-itch, vulnerary, for healing

vulnerary ${ }^{(27-28,31)}$

dermal, cicatrizant ${ }^{(27,51,59)}$

$500-$

1000
$125-250$

250-

500-1000

250-500

62.5-500

I

I

$\begin{array}{lll}\text { I } & \text { I }\end{array}$

I I

I

I I I

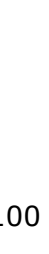


Postigo, A. Svetaz, L. Derita, M. Gette, M. A. Petenatti, M. Del Vitto,L. Petenatti, E. Zacchino, S. Revista Eletrônica de Farmácia Vol. IX (1), 18 - 39, 2012.

40

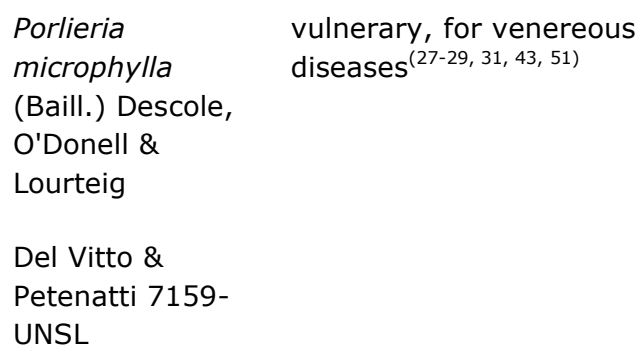

Table 2: Antifungal activities (MIC in $\mu \mathrm{g} / \mathrm{mL}$ ) of plants selected at random

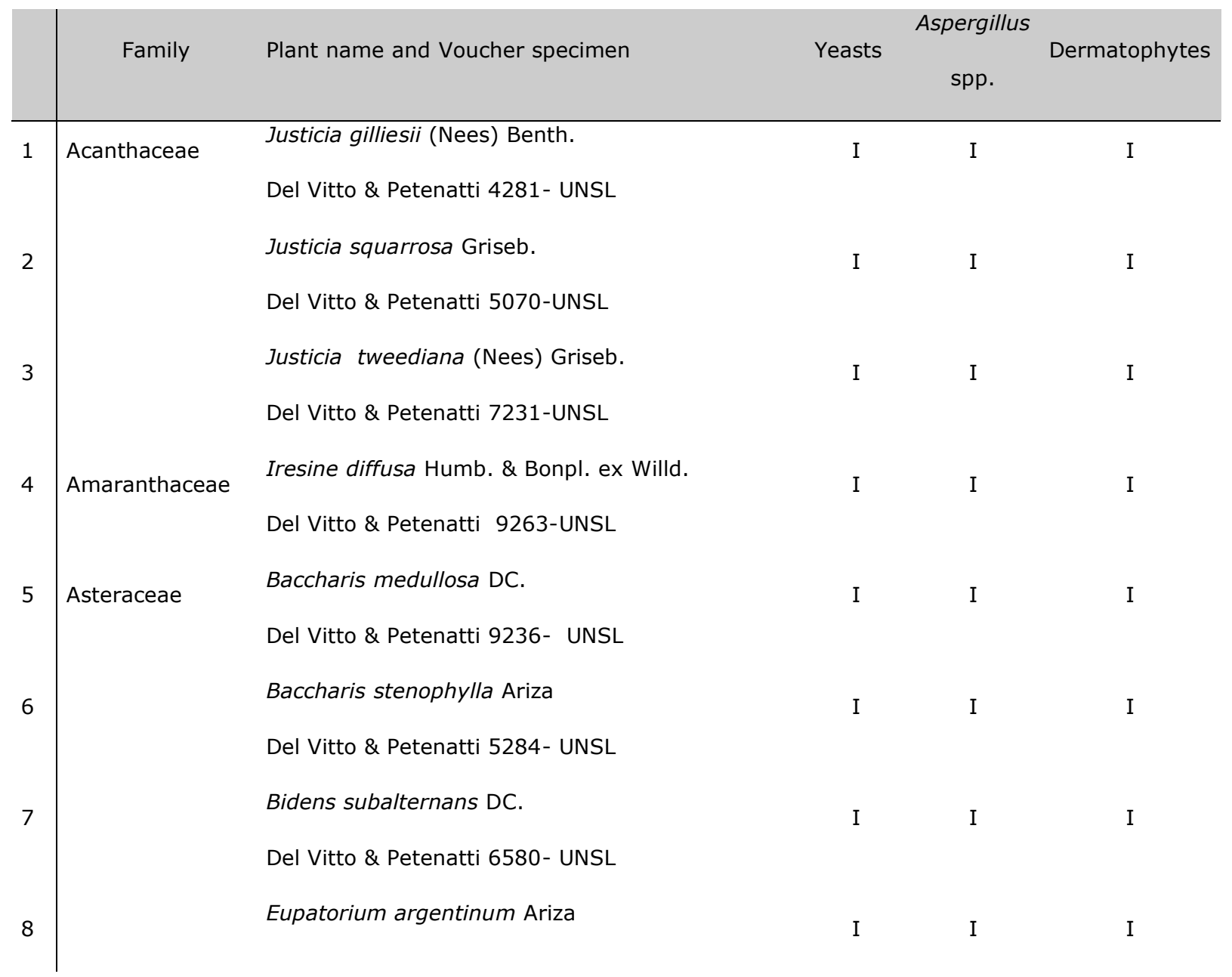


Postigo, A. Svetaz, L. Derita, M. Gette, M. A. Petenatti, M. Del Vitto,L. Petenatti, E. Zacchino, S. Revista Eletrônica de Farmácia Vol. IX (1), 18 - 39, 2012.

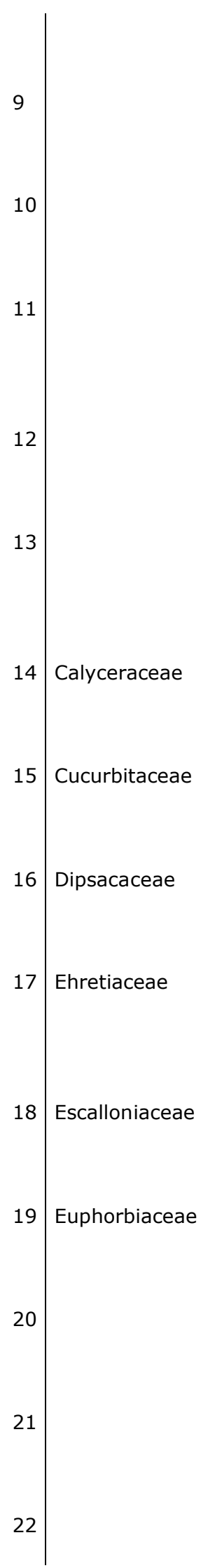

Del Vitto \& Petenatti 9281- UNSL

Gnaphalium gaudichaudianum DC.

Del Vitto \& Petenatti 9239- UNSL

Grindelia discoidea Hook. \& Arn.

Del Vitto \& Petenatti 9264- UNSL

Grindelia pulchella Dunal var. discoidea Bartoli \& Tortosa

Del Vitto \& Petenatti 9264- UNSL

Nassauvia axillaris (Lag. ex Lindl.) D. Don

UNSL 507

Thymophylla pentachaeta (DC.) Small var. belenidium (DC.) Strotter

Del Vitto et al. 8999-UNSL

Boopis anthemoides Juss.

Del Vitto \& Petenatti 9253 UNSL

Abobra tenuifolia (Gillies ex Hook. \& Arn.) Cogn.

Del Vitto \& Petenatti 9263- UNSL

Dipsacus fullorum L.

Del Vitto \& Petenatti 9424- UNSL

Ehretia cuneifolia Gottschling \& Hilger (= Cortesia cuneifolia Cav.)

Del Vitto \& Petenatti 9237- UNSL

Escallonia cordobensis (Kuntze) Hosseus

Del Vitto \& Petenatti 9309- UNSL

Croton argentinus Müll. Arg.

Del Vitto \& Petenatti 4615- UNSL

Croton hieronymi Griseb.

Del Vitto \& Petenatti 6625- UNSL

Croton parvifolius Müll. Arg.

Del Vitto \& Petenatti 9425- UNSL

Croton sarcopetalus Müll. Arg. 
Postigo, A. Svetaz, L. Derita, M. Gette, M. A. Petenatti, M. Del Vitto,L. Petenatti, E. Zacchino, S. Revista Eletrônica de Farmácia Vol. IX (1), 18 - 39, 2012.

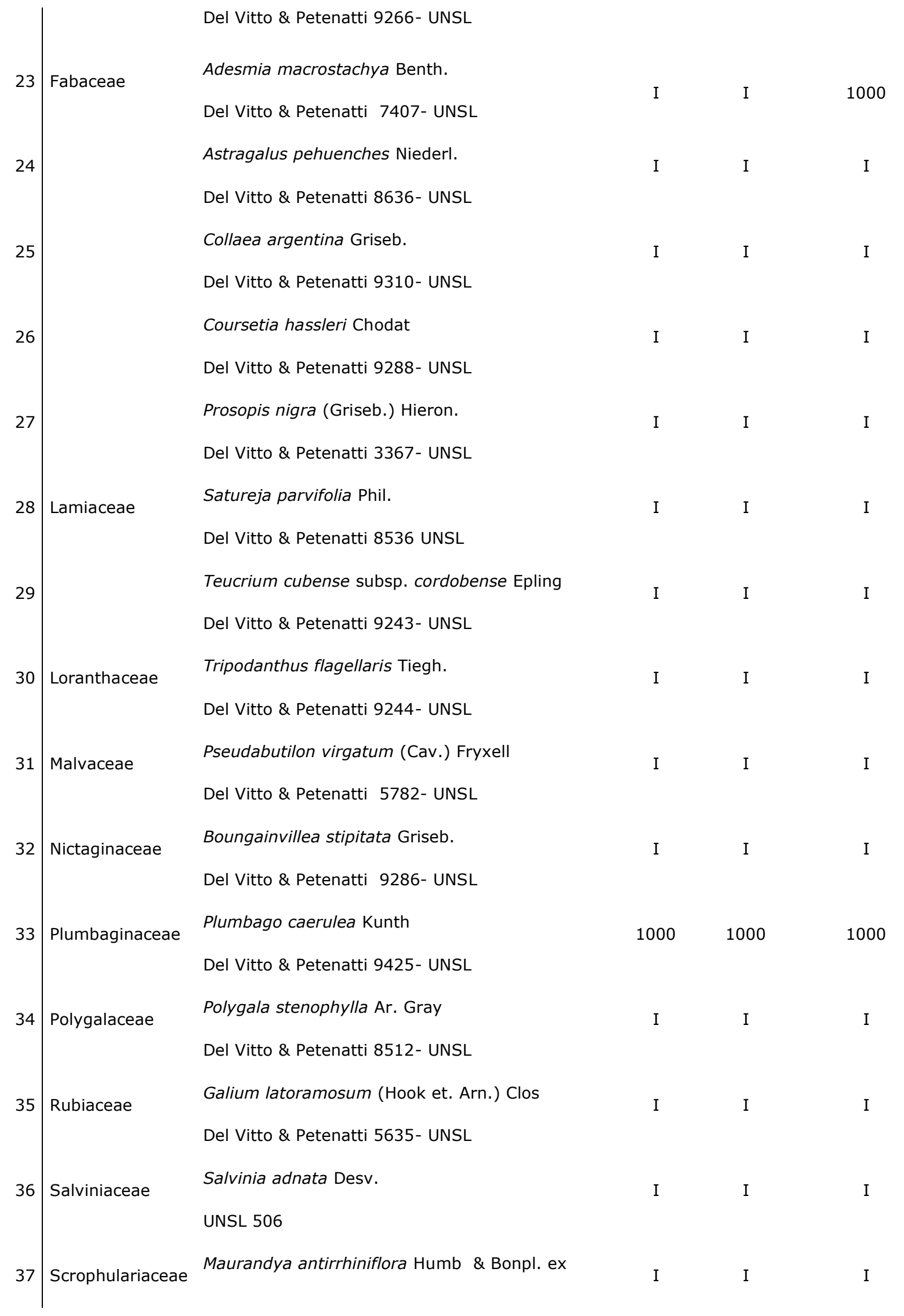


Postigo, A. Svetaz, L. Derita, M. Gette, M. A. Petenatti, M. Del Vitto,L. Petenatti, E. Zacchino, S. Revista Eletrônica de Farmácia Vol. IX (1), 18 - 39, 2012.

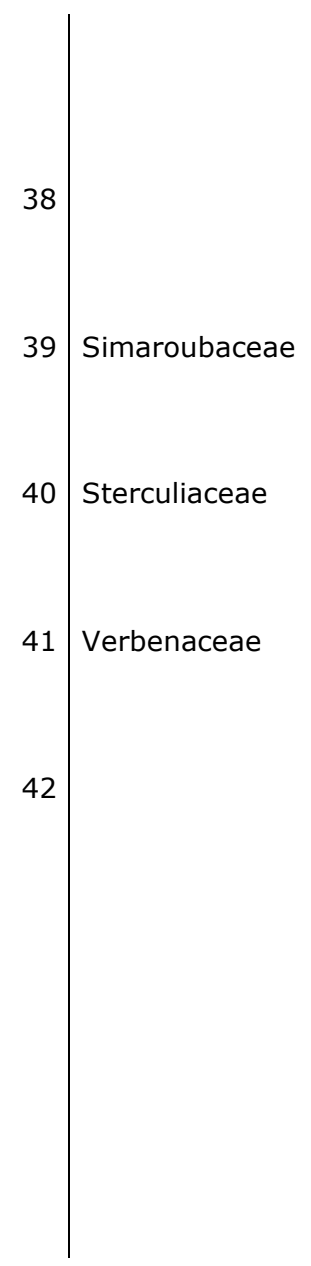

Willd.

UNSL 500

Agalinis communis (Cham. \& Schltdl.) D Arcy

Del Vitto \& Petenatti 7865- UNSL

Ailanthus altissima (Mill.) Swingle

Del Vitto \& Petenatti 3400- UNSL

Ayenia lingulata Griseb.

Del Vitto \& Petenatti 9251 - UNSL.

Lippia integrifolia (Griseb.) Hieron.

Del Vitto \& Petenatti 6089- UNSL.

Xeroaloysia ovatifolia (Moldenke) Tronc.

Del Vitto \& Petenatti 9252- UNSL

$\begin{array}{lcc}\text { Anfotericina B } & 0.25- & 0.5 \\ & 1.0 & \\ & & \\ \text { Ketoconazol } & 0.25- & 0.25-0.5 \\ & 0.5 & \end{array}$

Terbinafina

$0.01-0.04$

To analyze whether there is a significant difference in the percentage of the detected antifungal plants between PE and PW groups, the Pearson chi square test was applied. Results showed that there is a significant higher chance $(62.5 \%$ vs. $10 \%, p<0.01)$ of detected antifungal plants in unless one group of fungi, when the plant has a history of medicinal use related to antifungal properties (PE group) than when plants are chosen at random (PW group).
In addition, it is observed a clear trend of extracts to display lower MICs within PE group, against dermatophytes ( $p<0.01$ ) fungi responsible of superficial infections. These findings suggest that the ethnopharmacological approach is useful in guiding the discovery of antifungal plants in plants of San Luis province, mainly for infections in which the pathological expression can be clearly observed by the population.

This result is in concordance with our previous work regarding antifungal 
Postigo, A. Svetaz, L. Derita, M. Gette, M. A. Petenatti, M. Del Vitto,L. Petenatti, E. Zacchino, S. Revista Eletrônica de Farmácia Vol. IX (1), 18 - 39, 2012.

activity of plants of Latin America ${ }^{(26)}$ but here, within plants of San Luis province, it could be observed a more pronounced correlation between ethopharmacological data and antifungal behavior, both works clearly suggesting that the ethnopharmacological approach is useful in guiding the discovery of antifungal plants.

\section{Acknowledgements. A CONICET, ANPCYT (PICT 995), a UNR}

\section{REFERENCES}

1. Pfaller MA, Diekema DJ. Epidemiology of invasive candidiasis: a persistent public health problem. Clin. Microbiol. Rev. 2007,20:133-163.

2. Wilson LS, Reyes CM, Stolpman M, Speckman J, Allen K, Beney J. The direct cost and incidence of systemic fungal infections. Value Health. 2002;5:26-34.

3. Segal BH, Kwon-Chung J, Walsh TJ, Klein BS, Battiwalla M, Almyroudis NG, et al. Immunotherapy for fungal infections. Clin. Infect. Dis. 2006;42:507-515.

4. Nucci M, Marr KA. Emerging fungal diseases. Clin. Infect. Dis. 2005,41:521-526.

5. Freixa B, Vila R, Vargas L, Lozano N, Adzet T, Cañigueral S. Screening for antifungal activity of nineteen Latin American plants. Phytother. Res. 1998;12:427-430.

6. Ablordeppey S, Fan P, Ablordeppey J, Mardenborough L. Systemic antifungal agents against AIDS-related opportunistic infections: current status and emerging drugs in development. Curr. Med. Chem. 1999;6:1151-1195.

7. Mathew B, Nath M. Recent approaches to antifungal therapy for invasive mycoses. ChemMedChem. 2009;4:310-323.

8. Mukherjee PK, Leidich SD, Isham N, Leitner I, Ryder NS, Ghannoum MA. Clinical Trichophyton rubrum strain exhibiting primary resistance to terbinafine. Antimicrobial Agents and Chemotherapy. 2003,47:82-86.

9. Maragesi SM, Pieters L, Ngassapa OD, Apers S, Vingerhoets R, Cos P, Van Den Berghe DA, Vlietinck AJ. Screening of some Tanzanian medicinal plants from Bunda district for antibacterial, antifungal and antiviral activities. J. Ethnopharm. 2008,119:58-66. 
Postigo, A. Svetaz, L. Derita, M. Gette, M. A. Petenatti, M. Del Vitto,L. Petenatti, E. Zacchino, S. Revista Eletrônica de Farmácia Vol. IX (1), 18 - 39, 2012.

10. Danelutte AP, Lago JH, Young MC, Kato MJ. Antifungal flavanones and prenylated hydroquinones from Piper crassinervium Kunth. Phytochemistry. 2003;64:555-559.

11. Pacciaroni A, Gette M, Derita MA, Ariza Espinar L, Gil RR, Zacchino SA, et al. Antifungal activity of Heterothalamus alienus metabolites. Phytother. Res. 2008;22:524528.

12. Agüero M, Alvarez S, Luna L, Feresin G, Derita M, Tapia A, Zaacchino S. Antifungal activity of Zuccagnia punctata Cav. Evidences for the mechanism of action. Planta Medica. 2007;73:1074-1080.

13. Malheiros A, Cechinel Filho V, Schmitt C, Yunes R, Escalante A, Svetaz L, et al. Antifungal activity of drimane sesquiterpenes from Drymis brasiliensis using bioassayguided fractionation. J. Pharm. Pharmaceut. Sci. 2005;8:335-339.

14. Ríos JL, Recio MC. Medicinal plants and antimicrobial activity. J. Ethnopharm. 2005,100:80-84.

15. Cáceres A, López BR, Giron MA, Logemann H. Plants used in Guatemala for the treatment of dermatophytic infections. 1. Screening for antimycotic activity of 44 plant extracts. J. Ethnopharm. 1991;31:263-276.

16. McCutcheon AR, Ellis SM, Hancock REW, Towers GHN. Antifungal screening of medicinal plants of British Columbian native peoples. J. Ethnopharm. 1994;44:157-169.

17. Jones NP, Arnason JT, Abou-Zaid M, Akpagana K, Sánchez-Vindas P, Smith ML. Antifungal activity of extracts from medicinal plants used by First Nations Peoples of eastern Canada. J. Ethnopharm. 2000;73:191-198.

18. Coelho-de-Souza G, Haas APS, Von Poser GL, Schapoval EES, Elisabetsky E. Ethnopharmacological studies of antimicrobial remedies in south of Brazil. J. Ethnopharmacol. 2004;90:135-143.

19. Cruz MCS, Santos PO, Barbosa Jr A, De Mélo DLFM, Alviano CS, Antoniolli AR, et al. Antifungal activity of Brazilian medicinal plants involved in popular treatments of mycoses. J. Ethnopharm. 2007;111:409-412. 
Postigo, A. Svetaz, L. Derita, M. Gette, M. A. Petenatti, M. Del Vitto,L. Petenatti, E. Zacchino, S. Revista Eletrônica de Farmácia Vol. IX (1), 18 - 39, 2012.

20. Braga FG, Bouzada MLM, Fabri RL, Matos MO, Moreira FO, Scio E, Coimbra ES. Antileishmanial and antifungal activity of plants used in traditional medicine in Brazil. J. Ethnopharm. 2007,111:396-402.

21. CLSI. Clinical and Laboratory Standards Institute, formerly NCCLS, National Committee for Clinical and Laboratory Standards. Reference method for broth dilution antifungal susceptibility testing of yeasts; Approved Standard, 2nd edition, 2002. NCCLS document M27-A2, NCCLS, Wayne, PA. Reference method for broth dilution antifungal susceptibility testing of filamentous fungi; Approved Standard, 1st edition, NCCLS document M 38 A, Wayne, PA.

22. Ghannoun M, Ibrahim A, Fu Y, Shafiq M, Edwards J, Criddle R. Susceptibility testing of Cryptococcus neoformans: A Microdilution Technique. J. Clin. Microbiol. 1992;28812886.

23. Ho PL, Yuen KY. Aspergillosis in bone marrow transplant recipients. Critical Review on Oncology/Hematology. 2000;34:55-69.

24. Manuel RJ, Kibbler CC. The epidemiology and prevention of invasive aspergillosis. J. Hosp. Infect. 1998;39:95-109.

2.5 Weitzman I, Summerbell R. The dermatophytes. Clinical Microbiology Reviews. 1995;8:240-259.

26. Svetaz, L., Zuljan, F., Derita, M., Petenatti, E., Tamayo, G., Cáceres, A., Cechinel Filho, V., Giménez, A., Pinzón, R., Zacchino, S., Gupta, M.Derita M.

27. Toursarkissian M. Plantas Medicinales de la Argentina. Sus Nombres Botánicos, Vulgares, Usos y Distribución Geográfica. Buenos Aires: Ed. Hemisferio Sur; 1980.

28. Del Vitto L, Petenatti E, Petenatti M. Herbal resourses of San Luis (Argentina), first part: Native plants. Multequina. 1997;6:49-66.

29. Barboza GE, Cantero JJ, Núñez CO, Ariza Espinar LA. Flora Medicinal de la Provincia de Córdoba (Argentina). Córdoba: Museo Botánico; 2006.

30. Carrizo E del V, Palacio M, Roic L. Plantas de uso medicinal en la flora de los alrededores de la ciudad de Santiago del Estero (Argentina). Dominguezia 2002;18(1):26-35. 
Postigo, A. Svetaz, L. Derita, M. Gette, M. A. Petenatti, M. Del Vitto,L. Petenatti, E. Zacchino, S. Revista Eletrônica de Farmácia Vol. IX (1), 18 - 39, 2012.

31. Hieronymus J. Plantae Diaphoricae Florae Argentinae. Buenos Aires, Argentina; 1882.

32. Bustos D, Tapia A, Feresin G, Ariza Espinar L. Ethnofarmacobotanical encuesta del distrito Bauchazeta, provincia de San Juan, Argentina. Fitoterapia. 1996;67:411-415.

33. Roig F. Flora Medicinal Mendocina. Las Plantas Medicinales y Aromáticas de la Provincia de Mendoza (Argentina). Mendoza, Argentina: Ed. Ediunc; 2001.

34. Hadad M, Zygadlo JA, Lima B, Derita M, Feresin GE, Zacchino SA, Tapia A Chemical composition and antimicrobial activity of essential oil from Baccharis grisebachii Hieron (Asteraceae). J Chilean Chem. Soc. 2007;52:1186-1189.

35. Marzocca A. Index de plantas colorantes, tintóreas y curtientes. Manual de las especies argentinas. Buenos Aires: Ser. Acad. Nac. Agronomía y Veterinaria; 1993.

36. El-Shabrawy A.O. Essential oil composition and tannin contents of the leaves of Eugenia uniflora L. grown in Egypt. Bulletin of the Faculty of Pharmacy Cairo University. $1995 ; 33: 17-21$.

37. Schulz A. Algunas plantas usuales del noreste argentino Parodiana. 1997;10:211241.

38. Bashir A, Janbaz KH, Uzair M, Ejaz AS. J. Res. Sci. 2001;12:85.

39. Alonso J, Desmarchelier C. Plantas medicinales autóctonas de la Argentina. Bases científicas para su aplicación en atención primaria de la salud. Buenos Aires: Fitociencia, 2006.

40. Amat A. Taxones de Compuestas Bonaerenses críticos para la investigación farmacológica. Acta Farm. Bonaerense. 1983;2:23-36.

41. Zardini E. Enobotánica de Compuestas Argentinas con especial referencia a su uso farmacológico. Acta Farm. Bonaerense. 1984;3 (1):77-99.

42. Rosella MA, Castillo A, Romero L, Spegazzini E, Ureña L, González J, Ortega-Barria E, Debenedetti S. Actividad antiparasitaria de Gaillardia spp. (Asteraceae). Lat. Am. J. Pharm. 2007;26:270-274.

43. Nuñez C, Cantero J. Las Plantas Medicinales del Sur de la Provincia de Córdoba. Córdoba, Argentina: Fundación Universidad Nacional Río Cuarto; 2000. 
Postigo, A. Svetaz, L. Derita, M. Gette, M. A. Petenatti, M. Del Vitto,L. Petenatti, E. Zacchino, S. Revista Eletrônica de Farmácia Vol. IX (1), 18 - 39, 2012.

44. Vivot E, Muñoz J, Cruañes M, Escalante A, Sortino M, Zacchino S, López S. VII Simp. Latinoam. Farmacobotánica, Comodoro Rivadavia, Argentina. 2001.

45. Rossi J, Talavi A, Juárez S, Spegazzini E, Zacchino S, Debenedetti S. Actividad antifúngica de tres especies del género Pterocaulon, Resumen del VIII Simposio Argentino y XI Simposio Latinoamericano de Farmacobotánica, Buenos Aires. 2004.

46. Quiroga E, Sampietro A, Vattuone M. Screening antifungal activities of selected medicinal plants. J. Ethnopharmacol. 2001;74:89-96.

47. Zygadlo L, Guzmán C, Grosso N. Antifungal properties of the leaf oils of Tagetes minuta L., T. filifolia Lag J. Ess. Oil Res. 1994;6:617-621.

48. Fenner R, Heemann Betti A, Auler Mentz L, Kuze Rates SM. Plantas utilizadas na medicina popular brasileira com antifúngica Atividade potencial. Brazilian J. Pharm. Sci. 2006;42:369-394.

49. Martínez Crovetto R. Las plantas utilizadas en medicina popular en el noroeste de Corrientes (Rep. Arg.). Miscelánea (Tucumán) 1981;69:1-139.

50. Marzocca A. Vademecum de malezas medicinales de la Argentina indígenas y exóticas. Argentina: Ed. Orientación Gráfica; 1997.

51. Novara L. Las Utilidades de los Géneros de Antófitas del Nordeste del Valle de Lerma (Salta, República Argentina). Salta: Fac. Cs. Nat., Univ. Nac.; 1984.

52. Ponessa de Mercado G, Parrado de Jalil M, Horta A, Sosa F. Plantas medicinales del Valle de Tafí, Tucumán, Argentina, Resumen de las XXV Jornadas Argent. Bot. Mendoza, Argentina. 1996.

53. Sorarú S, Bandoni A. Plantas de la medicina popular argentina. Buenos Aires: Ed. Albatros; 1978.

54. Martínez Crovetto R. Estudios etnobotánicos I. Nombres de plantas y su utilidad según los indios tobas del este del Chaco. Bonplandia. 1964;1:279-333.

55. Feresin GE, Tapia A, Sortino M, Zacchino S, Arias ARD, Inchausti A, Yaluff G, Rodriguez J, Theoduloz C, Schmeda-Hirschmann G. Bioactive alkyl phenols and embelin from Oxalis erythrorhiza. J. Ethnopharmacol. 2003; 88:241-247. 
Postigo, A. Svetaz, L. Derita, M. Gette, M. A. Petenatti, M. Del Vitto,L. Petenatti, E. Zacchino, S. Revista Eletrônica de Farmácia Vol. IX (1), 18 - 39, 2012.

56. Gupta M. (ed.). 270 Plantas Medicinales Iberoamericanas. Bogotá: CYTED-SECAB; 1995.

57. Muñoz S, Barrera M, Meza P. El Uso Medicinal y Alimenticio de Plantas Nativas y Naturalizadas en Chile. Santiago: Museo Nacional de Historia Natural; 1981.

58. Zacchino S, Santecchia C, López S, Gattuso S, Muñoz J, Cruañes A, Vivot E, Cruañes $M$, Salinas $A$, Ruiz $R$, Ruiz $S$. In vitro antifungal evaluation and studies on mode of action of eight selected species from the Argentina flora. Phytomedicine. 1998;5:389-395.

59. Filipov A. La farmacopea natural en los sistemas terapéuticos de los indígenas Pilagá. Parodiana. 1997;10(1-2):35-74. 